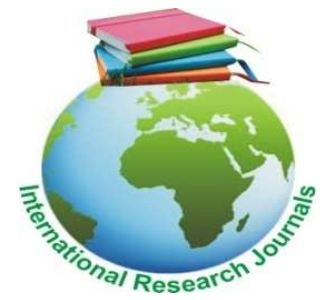

International Research Journal of Agricultural Science and Soil Science (ISSN: 2251-0044) Vol. 7(1) pp. 008-011, February, 2017

DOI: http:/dx.doi.org/10.14303/irjas.2017.021

Available online http://www.interesjournals.org/IRJAS

Copyright (C) 2017 International Research Journals

Full Length Research Paper

\title{
Improvement of methods for receiving high quality grape saplings by in vitro method
}

\author{
Sultanov K.S. \\ Tashkent State Agrarian University, Tashkent Uzbekistan \\ Corresponding Author's E-mail: prof.buriev@mail.ru
}

\begin{abstract}
The most important link of nursery garden is the production of the certified cuttings and saplings from super intensive mother plantation. The perspective trend in nursery gardening is growing saplings with closed root system [a container crop] on the artificial substratum and soil substitutes. It allows planting of green cuttings (grafts) and test-tube plants into open ground in any season. Taking into account of these circumstances there is necessity of improvement methods and adaptation ways of test-tube plants of grape to non-sterile conditions came into being.
\end{abstract}

Keywords: Grape, Varieties, Saplings quality, Adaptation, Reproduction, In vitro, Virus free, Growing.

\section{INTRODUCTION}

Recently vineyards of the Republic have been exposed to chronic diseases of virus, mycoplasma and bacterium origin. The most wide-spread and harmful of virus diseases are fatigue striation, leaf roll, fan leaf of grape and infectious chlorosis and of bacterium cancer and bacterium necrosis.

The virus diseases are especially dangerous for their being hereditary in vegetative reproduction, spreading at transportation of planting stocks and some of them are transferring from infected vines to healthy ones through nematodes in soil.

The virus diseases cause degeneration and loss of vines, having the yield, quality of product and output of under stocks brought down. The development of diseases and bacterium cancer are chronic. The infested plants remain diseased during their lifetime after infection and all their parts are infectious too.

Nowadays in all wine-growing regions where virus and mycoplasma diseases are spread, the scientific research institutions are struggling against them using phytosanitary selection (clone selection): improving planting stock and reproduction of healthy plants in nutritious mediums.

For production of planting material of high quality grapes through the crop in vitro it necessary to develop highly effective and economical methods of accelerated reproduction of plants. (Batukayev and Smirnov 2011)

For producing grape planting stock of high quality categories through crop in vitro it is necessary to develop high efficiency and economical methods of accelerated plant reproduction. (Zlenko 2005, 2008)

Scientific researches held in many industrial and agricultural developed countries show that producing of high quality and free planting stocks is one of the perspective trends of efficiency increase of fruit bearing plants and grape growing. Planting in industrial gardens of such saplings provides plants with high adaptability to external factors, early maturing, high constant productivity for years of fruiting. Thus fast return of investments andhigh income in comparison with the usage of common planting stock will be provided. The final stage of the research on getting the virus free planting stock is the creation of stool bed from the saplings improved by in vitro method. (Medvedeva and Polivor 2008)

The most important link of nursery garden is the production of the certified cuttings (grafts) and saplings from super intensive mother plantation. The perspective trend in nursery gardening is growing saplings with closed root system [a container crop] on the artificial 
substratum and soil substitutes. It allows planting of green cuttings (grafts) and test-tube plants into open ground in any season. (Doroshenko and Semyonova 2000)

Taking into account of these circumstances there the necessity of improvement methods and adaptation ways of test-tube plants of grape to non-sterile conditions came into being. (Kutzenko and Kulintzev 2011)

\section{RESEARCH METHODOLOGY}

The experiments were made in Tashkent State Agrarian University and the Scientific Research Institute of Microbiology in 2015-2016. In the experiment the following industrial and table varieties of grape like Kara Gouzal, Pink Taifee, Cabernet Savignon, Saperavi, pink Muscadine, Tavkveru and Katta Kurgan were used as the plant donors. Cultivating of meristem was done in testtube on the artificial soil extract agar medium M 1.After micro cutting of received clones the micro shoots were rooted in soil extract mediums №1 and № 4. Plants with good root system were replanted in vivo. For working out the adaptation of the improved test-tube grape plants the experiment were made by the following scheme:

\section{Experiment 1}

The research on making of virus and bacterium free grape stool was carried out. The experiment was made with above mentioned varieties of grape. For the research, firstly, a visual testing of mother clone plants on absence of bacterium cancer was made in the varieties stool beds of the Scientific Research Institute after M.M. Mirzayev. The bacterium cancer free clones were tested on the absence of virus diseases using herbaceous indicators and serbilogic serum, the initial healthy and improved plants were Super Super-Elite (SSE) and progenitors of improved clones. The vegetative nursling of the first reproduction of these plants was of Super-Elite ones. The planting stock resulted in the vegetative reproduction of Super-Elite was of certified elite ones.

\section{Experiment 2}

Planting of test-tube for implanting through in vitro method. The research was held in transplantation types where the plants were transplanted into $250 \mathrm{ml}$ and 450 $\mathrm{ml}$ plastic cups with soil substratum without sterilization. The content of soil mixture supper peat, natural mineral components with full composition of micro and macro elements with $\mathrm{PH}$ 6.0-6.5, the nitrogen content $\left(\mathrm{NH}_{4}\right.$ $\left.+\mathrm{NH}_{3}\right)-120-160$, phosphorus $\left(\mathrm{P}_{2} \mathrm{O}_{5}\right)-80-120$ and potassium $\left(\mathrm{K}_{2} \mathrm{O}\right)-100-140 \mathrm{mg} / 100$ of dry substance. Before planting the «Psevdobacterine»-12.5 and
«Extrasol» $-10 \mathrm{ml} / \mathrm{l}$ were injected into the substratum. The further development of plants occurred in the room with temperature of $20^{\circ} \mathrm{C}$, light $-4-5$ thousand luces. Watering was done necessarily with alternation of water and bio stimulating solution TERRA SORB foliar- $0.5 \mathrm{ml} / \mathrm{l}$ of water (mixture of amino acids). Growing of the adapted test tube plants was held in 250 and $450 \mathrm{ml}$ plastic cups, 1/3 filled with universal soil substratum and «Extrasol» in 12,5 and $10,0 \mathrm{ml} / \mathrm{l}$ of water, accordingly at $65 \%$ of moisture of substratum and covered with Petry cubs.

\section{Experiment 3}

Technology of growing of test tube plants in mineralcotton cubes. The research was held for working out the technology of growing test-tube plants in mineral-cotton cubes. The mass of dry cubes of artificial soil was of 200 $\mathrm{gr}$ filled with nutrient solution with mass of $650 \mathrm{gr}$, after water being flowed out of the cube is $400 \mathrm{gr}$. The relative moisture of soil was $62,2 \%$ coconut chips of dust fraction before soaked and washed with water for chlorine removalwas chosen as a stuff for filling of planting place or site.

After that the chosen coconut fraction was reduced to complete dryness. Planting place of the saplings in cube was made manually up to full depth of $2 \mathrm{~cm}$. The increasing of the depth level was made in order that the test-tube plants grow straight not in a form of spiral. Planting the plants by this method allowed the root system develops freely and consequently it wasn't deformed. The planting site was filled with dry washed coconut which in 15 minutes got saturated with moist from the cube. The relative moist of the air surrounding the plants was $80-90 \%$ and temperature $23-25^{\circ} \mathrm{C}$. Such conditions were not kept in the room but in the pellicle greenhouse. As cover stuff, white coarse calico fabric was used. Such way of planting can be applied in early march because the properties of cover stuff allow maintain rather high temperature in doors. Watering of the plants was held in the first period of growing-once in 2 weeks and after appearing the fifth internode by dipping the cube into the water up to incomplete saturation. After the first tendril appearing, the impregnation with nutrient solution of macro and micro elements was made. For pest and diseases treatment Falcon Ridomeel Gold, Konfidor extra preparations of $0.2 \%$ concentration were applied. Also once in 2 weeks the additional leaf fertilizing with amino acids and 1\% solutionof microelements in chelated forms of zinc, manganese, ferrum was mode as a disease and pest treatment mixture Falcon+Aktelick was applied around the green house site.

\section{RESULTS}

In the first experiment as a breeding nursery for 
010 Int. Res. J. Agric. Sci. Soil Sci.

reproduction of Super Super-Elite a site free of vineyard for 7 years was chosen. This is due to the fact that some virus diseases are transferred with nematodes which can normally breed only on the roots of grape plant-preserver of virus in soil. After having the infected plants stubbed up. Their roots stay alive in soil for 5-6 years and serve as a feed source for nematodes. After grape roots death the nematodes population dies. That's why for fight against nematodes cither the soil is given «a rest» from grape or disinfection of the soil with Nematizide DD 50\% technical and on thebasis of $2000 \mathrm{l} / \mathrm{ha}$ is made. The preparation is injected into the depth of $15 \mathrm{~cm}$ before making vineyard prior to 30 days before planting. It allows reduce the specified termin 2-3 times.

For the accelerated reproduction the initial mother vines Super Super-Elite were grown in greenhouses. Annually in spring, summer and autumn a visual testing of these vines for the presence of chronic diseases was held. Once in 5-6 years the mother plantations of Super Super- Elite were tested repeatedly for infection following by the removal or the infected vines. After having tested Super Super-Elites mother plantation and a visual selection of healthy plants was made for taking grafts from which nursery plants were grown.

Each clone was reproduced separately. These nursery plants were planted in the sites tree of vineyards tor 12 years. Every year these mother plantations were tested three times for possible infection of plants with chronic diseases. Then grafts were taken from healthy plants separately from each clone for growing planting materialcertified Elite used for making vineyards on the virus and bacterium free base (harmful virus and bacterium cancel free). For such vineyards, the sites which were free of vineyards for 7 years and where grains crops were grown before were $c$ chosen.

The varieties of scions and stocks of grapes which have not got any healthy clones are treated with thermotherapy method. For this after winter sleep at the beginning of the intensive growth, in pots they were placed into the heat chambers where they were grown for 2-6 months at constant temperature $38-40^{\circ} \mathrm{C}$ and with relative moisture o the chambers of less $2500 \mathrm{lk} / \mathrm{m}^{2}$. After having been heated the shoot apexes were cut, enrooted into pots and transferred into greenhouses where they were grown for a year. Next spring they were transplanted in the field on the special, virus disease sampling- nematode free sites. The grown plants were tested then the virus-free ones were taken and were reproduced thus obtaining Siaper-Elite one. The latter ones reproduction was speeded up with the method of propagation by herbaceous cuttings and the obtained planting material was planted into the live virus free mother plantation. Planting the healthy, virus and bacterium - free planting material provides longevity and high annual productivity of the plantings. In spite of the high percentage the actual percentage of grape clones that took root. In the 1 st experiment with the usage of big cups $-450 \mathrm{ml}$ the $250 \mathrm{ml}$ cups are preferable. In this case, the activity of physiological processes of developing plants was high, that was expressed bythe strength of sprouts and root system. Besides, in big cups of $450 \mathrm{ml}$ the moisture was kept for 10-12 days in high rates (80$65 \%$ ) white using of $250 \mathrm{ml}$ cups for only 5-6 days. The best taking root of explants showed the pink Muscadine variety $-100 \%$. Other varieties have the index that was significantly lower $23-25 \%$. In 3 weeks this variety (using 250 me cup) has 2 leaves of $6.1 \mathrm{~cm}$ long whereas using $400 \mathrm{ml}$ cup accordingly-3 leaves and roots of $15,5 \mathrm{~cm}$ long.

In the third experiment the root system of the grape shouted the mineral-cotton cube and gave side hairs. There the deformation of the plant root system was not observed. Having a weak root system the plant significantly was behind in growth and leaf system was developed. For such saplings we conducted a lot of measures that favored the improvement of the root system development: dried the cube up to $30 \%$ of the full moisture, the first watering was conducted with the application of aminoacids and humates that improved the root system development for $40 \%$. The analysis of taking root of plants depending on the soil showed that in peat pots with soil the taking root rate was much lower than in the cubes and it was $48,9 \%$ of pink Muscadine, pink Tayfy- $40 \%$, while in cubes- 82,0 and $72,0 \%$ relatively. In the result of the held researches it was proved that taking root and the development of test-tube plants in cubes was not more intensive than in pots which were used as the monitoring technique. The process of the root formation also was more active on the artificial soil from coconut in cubes.

When planting in June-July inside the greenhouse the night moist the cubes being $60 \%$ the sharp decrease of taking root level was observed at the same time, the adapted test-tube plants were planted in a net pavilion according to the compact planting scheme: between the rows $-20 \mathrm{~cm}$, between plants- $8 \mathrm{~cm}$ and the depth of planting $-10 \mathrm{~cm}$. The planting was held in 2 terms-in May and in June, The research revealed the advantage of transplanting of the adapted test tube plants from 20 May to early June. When planting in the second and third decades the percentage of the plants that took root was much lower. When planting the pink Muscadine on May21the percentage of survived plants was $87,2 \%$, when planting on June $20^{\text {th }}$ rate of taking root decreased to $52,0 \%$. The date planting effected significantly on the number of received green cuttings from the plant and on the sprouts maturing. The number of bud stick cuttings of the first planting date was 16-21 pieces of one bush, and 8-9 pieces of plants from the second planting date. The early planting date is preferable because it allows get more sprouts for rooting. At the time we can get the chance to get well-developed plants by the moment of optimal planting date on the constant site. 


\section{CONCLUSION}

1. Microclone grape growing is best made on the mineral cotton substratum using Extrasol $10 \mathrm{ml} / \mathrm{l}$ of water as the nutrient solution.

2. The optimal volume of plastic cups for adapted grape saplings growing is $400 \mathrm{ml}$ while transplanting of meristem tissues into the cups has to be held in the third decade of May.

3. The basic ways of grape saplings from the meristem tissues include the following one: maintaining disperse light in the room. The transplanting of test-tube stock into the greenhouse has to be done in March in the nutrient cubes of $400 \mathrm{gr}$ mass with the temper. of artificial substratum of $19-20^{\circ} \mathrm{C}$ and the air of $24-27^{\circ} \mathrm{C}$ additional fertilizers of macro and microelements for plants can be added white forming 5-6 internodes on the saplings.

\section{REFERENCES}

Batukayev AA, Smirnov KV (2001). Biotechnological methods of the accelerated reproduction of grape (in vitro). Agric. biotech. 2: 142158.
Zlenko VA (2005). Reproduction of the improved planting grape stock. Gardkning and grape growing.

Zlenko VA, Kotikov V (2008). In vitro methods for reproduction of the improved grape stock. 3:38-39.

Medvedeva NI, Polivor NV (2008). The teatures of microclone reproduction of introducent species and grape clones. Scientific J. KSAU. 137-155.

Doroshenko NP, Semyonova LN (2000). Adaptation to non-sterile conditions of improved test-tube grape plants. Regional conference publications. Stavropol. Russia. p.72.

Kutzenko AA, Kulintzev LG (2011). A sci.-based receiving of improved planting stock of valuable aborigen and perspective varieties of grape using modern biotech. methodology recommendations .Miknaylovsk.p.20. 